\title{
Meeting Immigrant Community College Students' Needs on One Greater Toronto Area College Campus
}

\section{KENISE MURPHY KILBRIDE \& LUCY D'ARCANGELO}

Ryerson University \& George Brown College

\section{ABSTRACT}

One hundred and forty-six students who entered Canada after their twelfth birthday and are now in one of six technical programs on a Greater Toronto Area (GTA) community college campus were surveyed. Technical programs enrol over half the students on this campus, and the six programs enrol over half the technical students. Over half had entered Canada past the usual age for high school (and over two-thirds in the past six years), making the college their point of entry into the Canadian educational system. Degrees and types of needs were analyzed, as well as degrees and sources of support. Differences occurred across numerous background traits but the most striking finding is the students' perception of a low degree of support from the college itself. This has clear policy implications for funders of GTA colleges, which attract such high numbers of new immigrants to Canada.

\section{RÉSUMÉ}

Notre échantillon se compose de cent quarante-six étudiants qui sont arrivés au Canada après l'âge de douze ans et qui font maintenant parti de l'un des six programmes du réseau collégial du Toronto métropolitain (GTA). Plus de la moitié de ces étudiants immigrants sont arrivés au 
Canada après l'âge habituel pour l'école secondaire (et plus des deux tiers sont arrivés au cours des six dernières années). Ainsi le collège est leur point d'entrée dans le système d'éducation canadien. Leurs besoins ont été analysés ainsi que les ressources qui leur étaient disponibles. Des différences ont été trouvées à travers plusieurs catégories, mais la différence fondamentale se retrouve surtout dans la perception de ces nouveaux arrivants d'une quasi absence d'aide financière offerte par le collège lui-même. Ceci est de grande importance pour les gestionnaires des collèges qui accueillent un grand nombre d'immigrants au Canada.

\section{OBJECTIVES AND PURPOSE OF THE STUDY}

This research project was designed to obtain a better picture of the needs of newcomer students. Community college faculty had been reporting with increasing frequency their concerns about this group of students in anecdotes they shared with the authors. In this study, we sought to clarify what those needs were and how commonly they were found among students whose first language was other than English. It further sought to identify the sources of support these students have or have not found in attempting to meet their needs. Additional information was requested to identify levels of education and professional training that students had obtained abroad and the extent to which those credentials had been recognized in Canada. No attempt was made to verify students' levels of academic accomplishment either here or in their home countries; this survey was simply an attempt to uncover how they themselves perceive and present their situation in terms of concerns and remedies.

This paper reports on quantitative data obtained regarding needs of immigrant college students and some ways in which they obtain help to meet those needs. Differences relating to place of origin, age at entry to Canada, levels of education recognized by Canada, and similar demographic variables are noted.

The importance of seeking this information arises out of faculty concerns that they are not meeting the needs of immigrant students, and that the numbers of such students on campuses in the Greater Toronto Area (GTA) are increasing. Limited data available on the enrolment of students 
whose first language is other than English confirm their perceptions: among mature students enroling on a single campus, for example, the percentages of non-native English speakers in Fall 1999 was 43\%, while in Fall 2000 it was 50\%; among Fall 2001 enrolments it was $76 \%$. What would have been helpful for this study would have been the existence of data on the number of foreign-born students entering the Canadian educational system for the first time through a community college, and the percentage of the total college population that such students comprise. Such data, unfortunately, seem not to exist.

\section{REVIEW OF THE LITERATURE}

One of the more striking aspects of the review of the literature conducted for this study is the absence of scholarly research in English on immigrant community college students, and the relative paucity of research on this age group of immigrants in general. Newcomers in the late teens and early 20 s are not a prime focus of attention for researchers, whose work tends to focus on younger children or high school youth. Studies of other immigrant youth groups that are close to this community college population have proved helpful, however: Lam's (1994) chapter on teen-aged immigrant students in the study by Anisef and Bunch (1994) on Canadian high school students is an excellent related Canadian example, as are Yau's (1995) exploratory study of refugee students in Toronto schools, Israelite and Herman's study (1999) of Latina immigrants and refugees, and with Alim, Mohamed and Khan (Israelite et al., 1999) in a study of Somali women refugees. For the most part, the studies that emerged in the search were American (e.g., London, 1990; McDonnell \& Hill, 1993; Portes \& Zhou, 1993; Zhou, 1996), with a few others from Europe (e.g., Tomlinson, 1991) or Australia (Wyn \& White, 1998).

The group of concern for this study, those who enter Canada either during junior or senior high school or later and go on to a community college, is apparently unstudied. Adult immigrants are more educated than native-born populations in Canada, the U.S., and Australia (Reitz, 1998), so for them the educational issues are different and tend to centre on receiving appropriate recognition for these credentials in an increasingly 
credential-oriented society. But the fundamental needs of immigrant community college youth, their goals, constraints, and experience of the new environment are not the focus of English-language research, nor is there any information about their school or labour attainments, mental health or other forms of well-being.

One theoretical framework of this study applies the ecological understandings of Urie Bronfenbrenner (1979) as informed by a critical theoretical approach (e.g., as in the work of Bernstein, 1974 and Bourdieu, 1977, 1983). The literature was therefore reviewed to identify what structures support, or fail to support, the integration of immigrant students into the surrounding dominant society at various levels. Karabel's classic study (1972) of the way in which community colleges serve to perpetuate social stratification is theoretically insightful, but the study references U.S. community colleges, and is not specifically useful to this research. Data in the literature examined were largely based on young immigrants who were being wholly or mainly supported by their families; this limitation meant that many if not all of their needs, other than adaptive needs, were being met. Since they needed no additional support, this literature cannot offer a wealth of examples of programs designed to assist immigrant students. Adaptive needs, however, relating to assistance with adjusting to a new educational system, new courses of study (or familiar courses of study taught in new ways or in a new language), language needs, and adjustment to a new culture in general were addressed in the literature, and these proved useful for designing a study of the needs of community college students.

A theoretical consideration that may well offer the richest insight into the needs of the students who are immigrants, however, is that of Ogbu (Gibson \& Ogbu, 1991), who distinguishes between immigrants and involuntary migrants and their relative educational attainment. He argues that the experiences of people who came involuntarily is different based partially on the nature of that involuntary experience but also on the perception that others have of them, with their resulting lower status in society. There are some parallels that can be drawn to the case of adolescent immigrants. Unlike much younger children who come secure in the family unit that surrounds and protects them, these adolescent immigrants 
come with the same sense of uprooting that their parents experience: where they lived, they had an identity additional to that of their identity within the heart of the family; they had friends, many of whom had been their friends all their lives. Like other "involuntary" migrants, they were not the originators of the decision to migrate, and unlike their parents, they had neither the sense of a freely-chosen, great adventure nor the advantage of an established working-role or career identity (no matter how difficult it would prove for parents to re-establish it abroad).

When they arrived, these young immigrants experienced the great sense of loss of friends and family members that their parents did, but without the consolation of having planned such a sacrifice for the sake of a greater good. While much younger brothers and sisters had the advantage of many years ahead of them in the school system to become accustomed to new ways and to succeed in this country, many of the older youth had a very short time to become successful educationally, so as to gain admittance to colleges and universities. If it takes about seven years to function as well in a second language as in a first language, then students who enter Canada after the age of ten or eleven simply do not have the time to "get up to speed" in time for the pre-university courses that will determine their chances at the programs of their choice. ${ }^{1}$

Those who cope well are likely to be those who refuse the role of outsider that is placed on such youth not only by their Canadian-born peers, but also by those co-ethnic youth who came much younger and hence who see them as foreign, reflecting a language and culture these more established youth may have in large part rejected. Anisef and Kilbride (2000), in a report on focus group interviews with immigrant youth, cite this as a not uncommon experience in the testimony of older immigrant youth. These interviews are part of a project to discover the needs of youth aged 16 to 20 , some of whom are in various levels of education and some of whom have dropped out or have completed their last level of education and are working. These "copers" may be those who themselves buy into the "great adventure" and take on a maturity earlier than they would have otherwise. In this mature independence, immigrant youth may seek to negotiate new identities that are secure in who they are, but are also free to admit change and growth. The purpose of this 
study, however, is to identify, for those who enter community colleges, the needs and the ways in which they obtain support in meeting them.

Most important among the literature reviewed, however, is an article by Jones and Dennison (1972), which, while clearly not current, indicates what is salient in meeting needs of community college students in order to enable them to succeed academically. This Vancouver study compared drop-outs with those who completed the college program; it concluded that all types of students (accomplished or not, serious or not) are forced to withdraw because of unmet needs such as financial assistance, academic assistance, and dissatisfaction with the instruction.

The literature review led only in part, therefore, to the conclusion that the research on immigrant community college students should clarify five types of needs: education, basic needs (food, clothing, and shelter), emotional or moral support (including that from someone of their own cultural background as well as that from other sources), financial support (for other purposes as well as for their education), and information on services (provided by agencies and governments to newcomers and others) and issues (including legal assistance and immigration-related issues); this last heading was intended to relate to information useful for assisting them with living, studying, or working in Canada as relatively new immigrants. Other sources for this conclusion as to the design of the research were:

- an examination of what the college itself offers in response to needs it has identified;

- discussions with community college faculty;

- informal discussions with immigrant students; and

- informal discussions with other researchers working in the field of needs of immigrant youth in general.

\section{REVIEW OF EXISTING COLLEGE SERVICES}

The assumption that the college should be meeting the needs of its immigrant students is based partly on a common-sense analysis of the role of educational institutions in society, but more directly on its mission statement, which commits it to enabling "students to succeed in 
achieving their individual career and life goals... [by ensuring] a high degree of satisfaction with the quality of our programs and services among students...".

The college has provided assistance to students both formally and informally. At the formal level it has done so to some extent in each of the five areas under consideration. It should be noted, however, that these provisions of assistance are made for all students and are not specifically offered with immigrant students in mind, despite the very high percentage each year of such students in its enrolment. While it is only education that the college is formally mandated and funded to provide, meeting the other needs of students has also been acknowledged as contributing to students' well-being and their ultimate academic success or failure. Given the current drop-out rate of almost $50 \%$ among students across community college campuses in Ontario, meeting these needs assumes a larger significance.

\section{Education}

Assistance with language and mathematics problems is provided in three ways at the college. First, some faculty members spend, according to anecdotal evidence, a considerable amount of time after class assisting individual students. Second, the Learning Resource Center, run by the Interdisciplinary Studies Department, ${ }^{2}$ provides help to students on a drop-in basis during a limited number of scheduled hours per week according to teacher availability (usually about ten hours). Such service, however, is based on whether provided funding is sufficient in any given year. There is no resource center to assist students with General Education and no peer tutoring. So the program teacher is the sole source of extra help. Third, there is a Peer-Tutoring Program for English and Math, which can be accessed through the counseling office.

In the Program departments, because specific programs have home rooms, such rooms serve as a collaborative area for students to assist each other. Some program teachers also spend considerable time in individual tutoring but most do not, again according to anecdotal evidence. 


\section{Basic Needs}

There is a food bank at each campus, but food supplies are often low and insufficient to satisfy the demand. Many students are not even aware that there is a food bank. Student Affairs and Counseling offer some assistance with housing and there are some approved postings on bulletin boards. Fashion students, on occasion, try to sell the garments they have prepared for their courses, but there are no real provisions for meeting clothing needs at the college.

\section{Emotional and Moral Support}

It is evident that students tend to socialize with students of their own background. Anecdotal information provides us with the information that students also seek friendships outside of their own background group. There are no postings to indicate that there are special interest groups or clubs. But, in general, the student association provides social activities and common meeting places.

\section{Financial Support}

The Ontario Student Assistance Program (OSAP) is the primary source of financial assistance obtained through the college. The college also organizes second-hand book sales to assist students to recycle texts. In urgent matters, the Student Affairs office may provide assistance with transportation costs and other urgent needs.

\section{Information on Issues and Services}

Immigration, government and agency service, and legal support information is available through the Student Affairs Office, the Student Association, or the Student Legal Assistance Office. A labour information day, called "Labour Fair," is an annual activity the aim of which is to provide workshops and speakers on workplace rights and responsibilities.

At the informal level, assistance is provided by faculty and students in a sporadic fashion. Students ask their classmates for help in preparing English, Mathematics, General Education, and program-specific assignments. Students often seek help from English professors in writing assignments for all their courses, not just English courses, and in preparing job 
search materials such as résumés and cover letters, according to most informal reports.

Anecdotal evidence also indicates that students ask individual faculty for money to obtain urgently needed basic supplies such as food for the day and transportation money to get home. Some also express anguish to faculty members regarding traumatic personal experiences, both past and current, and they seem to have nowhere else for such personal discussions. Such problems that had been brought to faculty thus contributed to the research design.

\section{RESEARCH METHODS}

\section{Research Questions}

In this study we attempted to identify perceived challenges to newcomer students in community colleges under the five general headings mentioned: education, basic needs, emotional and moral support, financial support, and information on issues and services. We also asked the frequency of each type of perceived need, whether it is being met, and by whom. This information was correlated with relevant demographic information, so as to obtain a clearer picture of which groups of students are being best served and which groups are in need of further attention, but the principal question for the researchers is the extent to which the college itself is in some way addressing identified needs.

\section{Study Design}

For each of the specified needs, students were asked to select how often they experienced the need, using a five-point scale: never, rarely, sometimes, often, very often. They were then asked whether that need is met, and if so by whom: the college, family members, friends, and others. Under the heading of education, students were asked to evaluate language, math, general education, and specific programs as sources of difficulties. Within basic needs, students were asked to comment on difficulties with food, clothing, and shelter needs. Under social and emotional support, students were asked to comment on their need for assistance from someone of their own background, friends, 
and the college. Under financial support, students were asked to specify educational or living costs. And under general information, students were asked to comment on their needs for information regarding immigration matters, legal assistance, or other services provided by government or other agencies. Students were also invited to check a response marked "other" under both types of needs and sources of assistance, and to specify what they meant by it.

\section{Methods}

The students in six technology programs on a community college campus were invited by faculty members to participate in this study. Self-selected students who entered Canada after their twelfth birthday were asked to complete a questionnaire. This sample may influence outcomes in two ways: first, the faculty who invited the students to participate were doing so because they had perceived difficulties that the students were experiencing, so the students in these programs may not be representative of every program on every campus; others may have fewer or more problems. Second, since the students were self selected, this sampling may have resulted in participation by a larger proportion of those who perceive that they are experiencing difficulties, rather than of those who believe they are doing well.

Anonymity was enhanced by having students from a nearby university serving as research assistants and taking the completed forms to their own campus for processing. Besides the objective questions on the three-page questionnaire, students were invited to write any other observations or comments on the back of the sheets. These were summarized by theme, using extensive quotations from the students' comments, in usual ethnographic form.

\section{Population}

The study consisted of a total of 146 students in six distinct programs on a community college campus in Toronto. Four programs were represented by 25 students, one by 24 students, and one by 22 students. They had all entered Canada after their twelfth birthday, and had come from North and South America, Africa, Asia, and Europe. Four students 
had completed the form who were found to have entered Canada before their twelfth birthday, thus invalidating four of the 150 forms.

Gender. Of the 146 students, 75 replied that they were male, 65 female, and 6 did not fill in that information.

Age. Twenty of the students were 20 years of age or less; 41 were in the 21 to 25 age category; 35 in the 26 to 30 age category; and 49 were 31 or over, including 10 who were 41 or over. One did not identify an age category.

Age upon Arrival in Canada. Fewer than half of these immigrant students had arrived in Canada during the usual high school years, which has clear implications for the responsibility of the college for integrating them into the Canadian system of education, as well as into their specific programs. Only 62 of the $145(42.8 \%)$ had arrived before their nineteenth birthday, yet almost $60 \%$ of these immigrant students arrived before the age of 21 , with the rest arriving as late as 48 years of age. Of this population of immigrant students, then, the sizable majority seem to have turned to a community college as their means of entering Canadian society and eventually its economy.

Geographical Origins. While six students did not complete this section, of the 140 who did, $81(55.5 \%)$ were from various parts of Asia excluding the Middle East, 19 (13\%) from Europe (one from Denmark, 18 from Southern or Eastern Europe, none from the British Isles or France), 16 (11\%) from the Americas including the Caribbean, 13 $(8.9 \%)$ from the Middle East, and 11 (7.5\%) from Africa.

Immigration Status. Of the 144 students who answered this part of the survey, 26 (18.1\%) had entered as refugees. Of the 142 who replied to a question on staged migration, however, $44(30.1 \%)$ had lived in another country after leaving their home country and before migrating to Canada.

\section{FINDINGS}

\section{Summary of Needs}

Community college students who had migrated to Canada after their 12th birthday were confirmed as having many needs. (See Table 1). These will be reported on in full; then the greatest needs will be discussed. 
Table 1

Needs of Immigrant Community College Students $(n=146)$

\begin{tabular}{|l|c|c|c|}
\hline Type of Need & Never/Rarely & Sometimes & Often/Very Often \\
\hline Education (in general) & $30.9 \%$ & $53.7 \%$ & $15.4 \%$ \\
Language & 18.8 & 34.0 & 47.2 \\
Math & 67.1 & 22.1 & 10.7 \\
General Education & 49.6 & 33.8 & 16.5 \\
Specific Program & 23.3 & 37.2 & 39.5 \\
\hline Basic Needs (in general) & $72.8 \%$ & $19.9 \%$ & $7.4 \%$ \\
Food & 78.6 & 12.1 & 9.3 \\
Shelter & 69.7 & 14.8 & 15.5 \\
Clothing & 78.3 & 14.5 & 7.2 \\
\hline Social-Emotional Support & $36.4 \%$ & $48.1 \%$ & $15.5 \%$ \\
Same entho-racial & & & \\
background & 39.9 & 37.8 & 22.4 \\
Any good friend & 39.9 & 37.8 & 22.4 \\
College Staff & 50.4 & 34.4 & 15.3 \\
\hline Financial Support & $43.4 \%$ & $16.8 \%$ & $12.9 \%$ \\
Education costs & 28.7 & 23.8 & 47.6 \\
Living Costs & 52.4 & 15.4 & 32.2 \\
\hline Information on Issues & & & \\
and services & $48.2 \%$ & $38.8 \%$ & $12.9 \%$ \\
Immigration matters & 52.1 & 33.1 & 14.8 \\
Government/agency & & & \\
services & 43.6 & 33.6 & 22.9 \\
Legal matters & 53.5 & 31.0 & 15.5 \\
\hline
\end{tabular}

Education. Of the 123 students who replied to this section: those who reported never or rarely needing help were $30.9 \%$ of the group; those reporting needing help sometimes were $53.7 \%$; and those reporting often or very often comprised $15.4 \%$. But respondents were also asked to reply regarding specific types of courses with which they might need assistance. The four types of education surveyed were: 
- language (generic English skills),

- math (generic mathematical skills),

- general education (i.e., all of the courses that are neither English or math, nor those of the student's specific program; examples include social sciences, liberal arts including ethics, and fine arts), and

- specific program courses.

Needs in language assistance overall occurred rarely or never for $18.8 \%$ of the 144 students who replied; sometimes for $34.0 \%$ of the students; and often or very often for the largest group of students, $47.2 \%$. Needs in math assistance occurred never or rarely for $67.1 \%$ of the 140 who replied; occurred sometimes for $22.1 \%$ of them; and occurred often or very often for $10.7 \%$ of them. Needs in general education occurred never or rarely for $49.6 \%$ of the 139 respondents; sometimes for $33.8 \%$ of them; and often or very often for $16.5 \%$. With regard to the specific program in which the students are enroled, the need for help occurred never or rarely for $23.3 \%$ of the 129 who replied; sometimes for $37.2 \%$; and often or very often for $39.5 \%$ of them.

Basic Needs. Students reporting never or rarely needing assistance with basic needs in general comprised $72.8 \%$ of respondents; those reporting needing such assistance sometimes were 19.9\%; and those needing it often or very often were $7.4 \%$ of the 136 who responded to this part of the survey. With regard to needing help in acquiring food, 140 replied: $78.6 \%$ needed such help never or rarely; $12.1 \%$ needed it sometimes; and $9.3 \%$ needed it often or very often. With regard to finding shelter, of the 142 who responded: $67.8 \%$ never or rarely needed such help; $14.4 \%$ needed it sometimes; and $15.1 \%$ needed it often or very often. With regard to clothing, 138 students replied: 78.3 needing such assistance never or rarely; $14.5 \%$ sometimes needing it; and $7.2 \%$ needing it often or very often.

Social-Emotional Needs or Need for Moral Support. There were 129 replies from students: $36.4 \%$ reported never or rarely needing such help; $48.1 \%$ sometimes needing it; and $15.5 \%$ needing it often or very often. Specifically, those needing "support from someone of the same 
ethnic background," 143 responded: of whom $39.9 \%$ never or rarely needed such help; $37.8 \%$ needed it sometimes; and $22.4 \%$ needed it often or very often. "Support from any good friend" received a reply from 143 students: of whom $39.9 \%$ never or rarely needed such help; $37.8 \%$ needed it sometimes; and $22.4 \%$ needed it often or very often. "Need for such support from college staff" drew a reply from 131 students: of whom $50.4 \%$ claimed they never or rarely needed such assistance; $34.4 \%$ sometimes; and $15.3 \%$ often or very often.

Need for Financial Assistance. This section was addressed by 143 students: $43.4 \%$ never or rarely needed such help, $16.8 \%$ needed it sometimes, and $39.9 \%$ needed it often or very often. With regard to "help with the costs of education," 143 replied: $28.7 \%$ never or rarely needed help; $23.8 \%$ needed it sometimes; and $47.6 \%$ needed it often or very often. With regard to "living costs," 143 replied, of whom $52.4 \%$ needed help never or rarely; $15.4 \%$ sometimes needed it; and $32.2 \%$ needed it often or very often.

Need for Information on Various Issues and Services. There were 139 students who addressed this: $48.2 \%$ never or rarely needed such help in general; $38.8 \%$ needed it sometimes; and $12.9 \%$ needed it often or very often. Regarding "immigration matters," 142 replied, of whom $52.1 \%$ rarely or never needed help; $33.1 \%$ needed it sometimes; and $14.8 \%$ needed it often or very often. For "information provided by government or agencies" 140 responded, of whom $43.6 \%$ needed help never or rarely; $33.6 \%$ needed it sometimes; and $22.9 \%$ needed it often or very often. Regarding information on legal services, 142 replied, of whom $53.5 \%$ never or rarely needed such help; $31 \%$ sometimes needed it; and $15.5 \%$ often or very often needed it.

While such needs vary widely across the types of assistance sought, seven of these needs were reported as "sometimes" or "often or very often" experienced by over half of the population (See Table 2). These top seven needs are help with: (1) language, (2) the specific program they are studying, (3) financing their education, (4) social or emotional support from someone of their own background, (5) social or emotional support from any good friend, (6) information on government or agency services; and (7) the general education courses they are taking. Thus three 
Table 2

Top Seven Needs of Most Immigrant Community College Students $(n=146)$

\begin{tabular}{|l|c|}
\hline Language assistance (Education need) & $81.2 \%$ \\
\hline Help with specific program (Education need) & $76.7 \%$ \\
\hline Help with education costs (Financial need) & $71.4 \%$ \\
\hline $\begin{array}{l}\text { Social-emotional support from a friend of the same ethno- } \\
\text { racial background }\end{array}$ & $60.2 \%$ \\
\hline Social-emotional support from any good friend & $60.2 \%$ \\
\hline $\begin{array}{l}\text { Information on government and agency services (Information } \\
\text { on issues and services) }\end{array}$ & $56.5 \%$ \\
\hline Help with general education courses (Education need) & $50.3 \%$ \\
\hline
\end{tabular}

of the seven needs are requests for help with education in some way: two for social or emotional support; one for financial assistance; and one for information about services available to them or their families.

\section{SUMMARY OF SOURCES OF ASSISTANCE}

Again, we shall begin with a presentation of where students received assistance for all the needs for which they sought help; then we turn to the areas of greatest need, and identify the sources of assistance for these (see Table 3).

Education. Of the 114 who needed assistance with language skills (of the 141 who replied), 95 received some help, and 19 did not receive any. Specifically, of the 95 needing help with language skills, 40 received help from the college; 22 from family; 47 from friends; and 16 from other sources. Of the 44 who needed assistance with math skills (of 137 who replied), 36 received some help, and 8 received no help. 
Table 3

Sources of Assistance for Students Needing It $(n=146)$

\begin{tabular}{|c|c|c|c|c|}
\hline \multirow[b]{2}{*}{ Need } & \multirow[b]{2}{*}{$\begin{array}{c}\text { Percent } \\
\text { in } \\
\text { Need }^{\star}\end{array}$} & \multicolumn{3}{|c|}{$\begin{array}{l}\% \text { from each type } \\
\text { of source }{ }^{* *}\end{array}$} \\
\hline & & College & Family & Friends \\
\hline Language assistance & 81.2 & 42.1 & 23.2 & 49.5 \\
\hline Math assistance & 32.8 & 41.7 & 44.4 & 30.6 \\
\hline Help with general education courses & 50.3 & 52.1 & 25.0 & 41.7 \\
\hline Help with specific programs & 76.7 & 57.7 & 19.2 & 42.3 \\
\hline Food & 21.4 & 10.0 & 60.0 & 30.0 \\
\hline Shelter & 30.3 & 8.0 & 61.5 & 23.1 \\
\hline Clothing & 21.7 & 0.0 & 90.0 & 5.0 \\
\hline Help with education costs & 69.1 & 45.7 & 43.5 & 10.1 \\
\hline Help with living costs & 47.6 & 19.5 & 65.9 & 12.2 \\
\hline $\begin{array}{l}\text { Social-emotional support from a friend of } \\
\text { the same ethno-racial background }\end{array}$ & 60.2 & 9.5 . & 45.9 & 74.3 \\
\hline $\begin{array}{l}\text { Social-emotional support from any good } \\
\text { friend }\end{array}$ & 60.2 & 16.3 & 28.8 & 82.5 \\
\hline $\begin{array}{l}\text { Social-emotional support from college } \\
\text { staff }\end{array}$ & 49.7 & 66.7 & $\mathrm{n} / \mathrm{a}$ & $\mathrm{n} / \mathrm{a}$ \\
\hline $\begin{array}{l}\text { Information on immigration matters } \\
\text { Information on services from government }\end{array}$ & 47.9 & 8.0 & 42.0 & 56.0 \\
\hline or agencies & 56.5 & 9.8 & 33.3 & 58.8 \\
\hline Information on legal matters & 46.5 & 10.3 & 30.8 & 66.7 \\
\hline
\end{tabular}

* For base, see in text the actual number of students replying to each question.

** Base is number of those actually needing help, see text.

The college provided help to 15 , the family provided help for 16 , friends provided help for 11 , and 4 got it from others. Of the 65 who needed help with general education (of the 133 who replied), 48 got help, and 17 got none. Specifically, the college provided help to 25 of 
them; the family to 12 of them, friends to 20 of them, and someone else to 1 . Regarding the students' specific program of enrolment, 91 needed help (of the 120 who responded), 79 received some, and 12 received no help. The college provided help to 46 , family to 15 , friends to 43 , and someone else to 6 students.

Basic Needs. Regarding assistance with food, 28 needed help (of the 138 replying), 20 got it, and 8 didn't. The college provided help for 2 , family for 12 , friends for 6 , and someone else for 3 students. Regarding shelter, 39 needed it (of the 138 replying), 26 got it, and 13 didn't. The college provided help for 2 , family for 16 , friends for 6 , someone else for 3 students. Regarding clothing, 28 needed it (of the 136 replying), 20 got it, and 8 didn't. The college provided help for none, family provided it for 18 , friends for 1 , and someone else for 1 student.

Emotional and/or Moral Support. Regarding such support from someone of the same ethnic background, 84 students of the 140 who replied needed some assistance, 75 received it, and 9 didn't. The college provided support for 7 , family for 34 , friends for 56 , and someone else for 3. Regarding such support from any good friend, 90 needed help (of the 140 replying), 80 received it, and 10 didn't. The college provided help for 13 , the family provided it for 23 , friends for 66 , and someone else for 2 students. Regarding support from college staff, 60 needed help (of the 126 replying), 40 got it from the college, and 20 didn't.

Financial Support. Regarding such support for educational costs, 91 needed such help (of 132 replying), 69 received it, and 22 didn't. The college provided help to 32 , family to 30 , friends to 7 , and someone else to 17 . Regarding living costs, 63 needed such help (of 138 replying), 41 got it, 22 did not. The college provided help to 8 students, family to 27 , friends to 8 , and someone else to 11 .

Information on Issues and Services. Regarding such information on immigration matters, 68 needed such assistance (out of 141 replying), 49 received it, and 19 did not. The college provided it to 4 , family to 21 , friends to 28 , and someone else to 9 . Regarding such information on government or agency services, 75 needed assistance (out of 135 replying), 51 received it, and 24 did not. The college provided it to 5 students, families to 17 , friends to 30 , and someone else to 10 . Regarding information 
on legal support, 62 needed such assistance (out of 138 replying), 39 got it, and 23 didn't. The college provided it for 4 students, families to 12 , friends to 26, and someone else to 6 students.

For the seven areas of need in which most of the immigrant student population studied had - sometimes, often, or very often - sought help, there were only two areas in which the college offered help more often than not (See Table 4). Both of these areas have to do with course work: help with specific programs $(57.7 \%$ of the time they received help when they needed it); and help with their general education courses ( $52.1 \%$ of the times they received help from the college).

\section{DIFFERENCES IN NEED BY POPULATION CHARACTERISTICS}

While these are summarized here, a full discussion of the students' differences in needs, methods of meeting needs, and opinions on their condition and what should be done about it will occur in a later paper. This paper will give a brief overview of differences by gender and area of origin only.

\section{Gender}

Differences were apparent in two instances. First, within the section of the survey on the need for help in meeting life's "basic needs," females indicated a greater need for support than did males. In particular, over twice as many females expressed need for help in finding shelter than did males.

\section{Immigration status}

Differences between those entering Canada as immigrants and those entering as refugees also emerged: those who had had refugee status needed more help with finances (which is logical, given the nature of the hasty departure of refugees from their homeland).

\section{Origin}

Significant differences by geographical background occurred in the need for help in general, for help with education in general, and specifically 
Table 4

Sources of Assistance Received for Meeting Top Seven Needs for Those Who Need It $(n=146)$

\begin{tabular}{|l|c|c|c|c|}
\cline { 3 - 5 } \multicolumn{2}{c}{ Need } & $\begin{array}{c}\text { \% from each type } \\
\text { of source** }\end{array}$ \\
\hline $\begin{array}{c}\text { Percent } \\
\text { in } \\
\text { Need }\end{array}$ & College & Family & Friends \\
\hline Language assistance (Education need) & 81.2 & 42.1 & 23.2 & 49.5 \\
\hline $\begin{array}{l}\text { Help with specific program } \\
\text { (Education need) }\end{array}$ & 76.7 & 57.7 & 19.2 & 42.3 \\
\hline Help with education costs (Financial need) & 69.1 & 45.7 & 43.5 & 10.1 \\
\hline $\begin{array}{c}\text { Social-emotional support from a friend of } \\
\text { the same ethno-racial background }\end{array}$ & 60.2 & 9.5 & 45.9 & 74.3 \\
\hline $\begin{array}{c}\text { Social-emotional support from any good } \\
\text { friend }\end{array}$ & 60.2 & 16.3 & 28.8 & 82.5 \\
\hline $\begin{array}{c}\text { Information on government and agency } \\
\text { services (Information of issues and services) }\end{array}$ & 56.5 & 9.8 & 33.3 & 58.8 \\
\hline $\begin{array}{c}\text { Help with general education courses } \\
\text { (Education need) }\end{array}$ & 50.3 & 52.1 & 25.0 & 41.7 \\
\hline
\end{tabular}

* For base, see in text the actual number of students replying to each question.

** Base is number of those actually needing help, see text.

in a need for help with Math, in the need for socio-emotional support, and in the need for information regarding various services.

With regard to education in general, $100 \%$ of students from the Middle East stated they need help at least sometimes, $77 \%$ of those from Asia, $61.1 \%$ of those from Europe, $53.9 \%$ of those from the Americas (including the Caribbean), and $33.3 \%$ of those from Africa.

The need for help with Math also varies significantly: students from the Middle East and the Americas had the highest need, with $61.6 \%$ of those from the Middle East and $56.3 \%$ of those from the Americas needing help at least sometimes, compared to $33.3 \%$ of those from Asia, $22.2 \%$ of those from Africa, and $5.6 \%$ of those from Europe. 
The need for socio-emotional support from those of the same ethnic background also varied significantly by background: $75 \%$ of students from the Middle East wanted such help, as did 66.3\% from Asia, and $57.9 \%$ from Europe, while only $40 \%$ from Africa, and $31.3 \%$ from the Americas and Caribbean stated this as a need. The need for help and support from any good friend showed a similar and significant distribution: $75 \%$ for those from the Middle East, $66.3 \%$ from Asia, $57.9 \%$ from Europe, but only $40 \%$ from Africa and $31.3 \%$ from the Americas.

With regard to needing help with information on services provided by the government or agencies, again those from the Middle East, at $88.3 \%$, report the highest need, followed by $62.6 \%$ of those from the Americas, $58.5 \%$ of those from Asia, $36.8 \%$ of those from Europe, and $27.3 \%$ of those from Africa.

There are also significant differences by origin in need for help specifically with legal services: $66.6 \%$ of those from the Middle East reported such a need, $56.3 \%$ of Asian students, $37.5 \%$ of students from the Americas, $10.5 \%$ of those from Europe, and $10 \%$ of those from Africa.

Obviously, then, there is a significant difference in the degree of perceived need in general by region of origin: $85.7 \%$ of those from the Middle East, $66.7 \%$ of those from Africa, $56.2 \%$ of those from Asia, $27.3 \%$ of those from the Americas, and $12.5 \%$ of those from Europe reported needing help at least sometimes.

\section{DISCUSSION}

The discussion of findings will first address the college as a source of help in meeting the needs perceived by community college students who are recent immigrants, then focus on other sources of help besides the college.

We found that the college is only partially successful in assisting immigrant students to meet their needs, and that partial success varies markedly in different areas of need. Among the 14 types of help needed by students, the college succeeded in helping at least $50 \%$ of those in need in only two areas: help with their specific program $(57.7 \%)$, and help with general education courses $(52.1 \%)$. In three other areas the college was a source of assistance for fewer than half but over $40 \%$ of 
those who needed it: help with educational costs $(45.7 \%$, presumably through $\mathrm{OSAP}^{4}$ ), help with English (42.1\%), and help with math $(41.7 \%)$. As has been noted, both areas of success for a little over half of those needing it have to do with course work. But certainly language assistance is an obvious need for a college to target in providing assistance to immigrant students, in order to facilitate their success in education. This is identified as the biggest need, or the need of most students, yet the college provided assistance to only $42.1 \%$ of those who identified themselves as needing it.

In the remaining nine areas, fewer than $20 \%$ of the students obtained assistance from the college: in descending order, help with living costs (19.5), with emotional or moral support (any good friend) (16.3\%), with information on legal support (10.3\%), with food (10\%), with information on services provided by government or agencies $(9.8 \%)$, with housing needs $(8 \%)$, with information on immigration matters $(8 \%)$, and with clothing $(0 \%)$.

In this discussion of help provided by the college, it seems prudent to omit a consideration of the emotional and moral support of good friends, either of their own ethnic background or otherwise; presumably they are here linking these friends to the college as a source of support because they have met them on campus rather than because the college actively recruited such friends for them or provided formal support for ethno-specific student organizations either directly or through the Students Association; in fact, on this campus there are no such organizations.

Nevertheless, what is heartening is that to those seeking emotional or moral support from college staff ( 60 out of the 126 responding to this item), 40, or two thirds, received it. This is the highest score received by the college as a source of assistance to those in need.

Of the seven remaining types of help, the college ranks highest on assistance with living costs, but this is probably linked to the provision of OSAP, which includes living costs as well as educational costs in its expenses eligible for funding. This leaves two larger categories: basic needs, where the college seems rather useless: the students themselves organized their food bank, albeit on a different campus (10\%); shelter, usually considered a responsibility of colleges at least in terms of good 
information if not in terms of actual provision of housing, is here not really a target of college assistance in any significant way ( $8 \%)$; and, not surprisingly, there is no help at all in meeting clothing needs $(0 \%)$.

In theory, colleges need not concern themselves with housing because, unlike the universities, they are so widely scattered throughout the province that students are expected to reside at home, which accessibility is the intent of such dispersal. Nevertheless, colleges have increasingly specialized, with the result that an unknown number of students leave home to attend a college for its specific programs; so, independent of the needs of immigrant students for assistance with shelter, it is naive to think that college students in general have no need of a housing office on campus.

In the categories of need relating to information about provision of services in Canada (those from agencies or governments, those regarding legal matters, and those relating to immigration), the college was marginally useful, providing help to between $8 \%$ and $10 \%$ of those in need of it.

As for other sources of meeting needs, families are best, not surprisingly, in providing clothing (to $90 \%$ of those in need), living expenses (to $65.9 \%$ of those needing help), shelter (to $61.5 \%$ of those in need), and food (to $60 \%$ of those needing it), but they also manage to help with educational costs (to $43.5 \%$ of those needing help, very slightly less than the support provided through the college). They are significantly better than the college at providing information about Canadian programs of various types: $42 \%$ of those needing help with immigration matters found information through their own families; for information on government or agency services, $33.3 \%$ of those needing it got it from family members; and for legal matters, families provided the information for $30.8 \%$ of those needing it. Regarding social and emotional support, families provided it to $45.9 \%$ of those wanting help from someone of their own background, and to $28.8 \%$ of those wanting help from any good friend.

Friends provided the most help in these last two categories, information and social and emotional support. Regarding support, they provided it to $82.5 \%$ of those needing from any good friend and $74.3 \%$ to those needing it from someone of their own background. Furthermore, they were the most informative regarding Canadian programs: to $66.7 \%$ of 
those wanting information on legal matters, to 58.8 of those wanting it on government or agency assistance, and to $56 \%$ of those wanting information on immigration matters. Friends were also a source of help regarding educational matters: while fewer students got help from their friends than from the college regarding their specific programs, general education courses, or math, they were the biggest source of help for immigrant students wanting help with language, providing it for $49.5 \%$ of those needing it. For basic needs and financial assistance, friends were, not unreasonably, the weakest source of help, providing help that ranged from $5 \%$ for clothing to $30 \%$ for food. "Others" were also a source of marginal help, except for the educational and living expenses categories, where $24.6 \%$ and $26.8 \%$ of those needing assistance found help.

What must be remembered, however, regarding assistance provided by family and friends is the appropriateness of it vis- $\grave{a}-v i s$ the college as a potential source of that assistance. It would be highly unusual for family, for instance, to provide information as accurate as the college could regarding course work, language, or math. And information on government and agency services, needed by over half the immigrant student population, is more often provided by friends and family: again, is the college not a more likely source of accurate information? At least, it surely has access to such information, and presumably many people quite knowledgeable about how to access it and disseminate the information.

\section{CONCLUSION}

Given the number of areas where there are more immigrant students needing help than those who don't, what is most striking is the amount of unmet needs among immigrant community college students. Surely such needs must have been manifested in some way. The college seems to be best at helping through the informal caring of its teachers; witness the highest percentage received for emotional or moral support, and the better-than-half scores for help with the students' own programs and general education courses. What is missing is a structural recognition of the significant numbers of students for whom the community college is their introduction to Canada and the Canadian educational system. Further 
analysis of the qualitative part of this study should lead to a better understanding of who these students are, what their opinions are on their experiences, and what recommendations for community colleges could better address their needs. In addition, for their own planning purposes colleges need to collect more data on their students, particularly the foreign born, to understand the size of this population and the types and scope of their needs, in order to enhance their likelihood of success.

\section{Notes}

1 In Ontario, "Ontario Academic Credits" replace the former Grade 13; six of these courses now must be taken within the first four years of high school, typically toward the end, as a requirement for university. The loss of a fifth grade in high school may have posed difficulties for many students, but for youth still learning English, it is even more particularly a challenge.

2 The Interdisciplinary Studies Department houses all those faculty members who teach "Generic Skills," which are English and Math courses, and "General Education," which are courses such as psychology, sociology, philosophy, ethics, history, geography, religion, fine arts, business and finance.

3 These data under Social-Emotional Support in the areas of "same ethnoracial background" and "any good friend" have been tripley checked, as they were identical, but they are correct.

4 The Ontario Student Assistance Program (OSAP) is a loan program designed, authorized, and originally underwritten by the province, but administered through individual colleges and universities to which students apply and from which they receive admission to the program; hence, they think of it as assistance from the college or university. 


\section{References}

Anisef, P., \& Bunch, M. (1994). Introduction. In P. Anisef (Ed.), Learning and sociological profiles of Canadian high school students (pp. 1-18). Lewiston, NY: Edwin Mellen Press.

Anisef, P., \& Kilbride, K.M. (2000). Report on the needs of newcomer youth and emerging best practices to meet those needs. Toronto, ON: Ontario Administration of Settlement and Integration Services, Ministry of Citizenship and Immigration Canada.

Bernstein, B. (1974). Class, codes and control, 2nd ed. New York, NY: Schocken Books.

Bourdieu, P. (1977). Cultural reproduction and social reproduction. In J. Karabel \& A.H. Halsey (Eds.), Power and ideology in education (pp. 487-511). New York, NY: Oxford University Press.

Bourdieu, P. (1983). Forms of capital. In J. Richardson (Ed.), Handbook of theory and research for the sociology of education. New York, NY: Greenwood Press.

Bronfenbrenner, U. (1979). The ecology of human development. Cambridge, MA: Harvard University Press.

Gibson, M.A., \& Ogbu, J.U. (1991). Minority status and schooling: $A$ comparative study of immigrant and involuntary minorities. New York, NY: Garland Publishing.

Israelite, N., \& Herman, A. (1999). Voices of recent Latina immigrants and refugees: Effects of budget cuts on their settlement experiences. Paper presented at the Qualitative Analysis Conference, Fredericton, NB.

Israelite, N., Herman, A., Alim, F., Mohamed, H., \& Khan, Y. (1999) Experiences of Somali women refugees in Toronto. Paper presented at the Seventh International Congress of Somali Studies. Toronto, ON.

Jones, G., \& Dennison, J.D. (1972). A comparative study of persister and non-persister college students. (ERIC Document Reproduction Service No. ED062975).

Karabel, J. (1972). Community colleges and social stratification. Harvard Educational Review, 42, 521-562.

Lam, L. (1994). Immigrant students. In P. Anisef \& M. Bunch (Eds.), Learning and sociological profiles of Canadian high school students (pp. 122-130). Lewiston, NY: Edwin Mellen Press.

London, C. (1990). Educating young new immigrants: How can the United States cope? International Journal of Adolescence and Youth, 2, 81-100. 
McDonnell, M., \& Hill, P. (1993). Newcomers in American schools: Meeting the educational needs of immigrant youth. Santa Monica, CA: Rand Publications.

Portes, A., \& Zhou, M. (1993). The new second generation: Segmented assimilation and its variants. American Academy of Political and Social Science, 74-96.

Reitz, J. (1998). Warmth of the welcome: The social causes of economic success for immigrants in different nations and cities. Boulder, $\mathrm{CO}$ : Westview Press.

Tomlinson, S. (1991). Ethnicity and educational attainment in England: An overview. Anthropology and Education Quarterly, 22, 121-139.

Wyn, J., \& White, R. (1998). Young people, social problems and Australian youth studies. Journal of Youth Studies, I, 23-38.

Yau, M. (1995). Refugee students in Toronto Schools: An exploratory study (Report No. 211). Toronto, ON: Toronto Board of Education.

Zhou, M., \& Bankston, C.L. (1994). Social capital and the adaptation of the second generation: The case of Vietnamese youth in New Orleans. International Migration Review, 28, 821-845. 